\title{
Seasonal height-weight dynamics of western wheatgrass
}

\author{
JOHN E. MITCHELL, ROBERT ELDERKIN, AND JAMES K. LEWIS
}

\begin{abstract}
Authors are range scientist, Rocky Mountain Forest and Range Experiment Station, Fort Collins, Colo. 80526; multiresource specialist, USDI Bureau of Land Management, Glenwood Springs, Colo. 81602; and emeritus professor, Dept. Animal and Range Sciences, South Dakota State University, Brookings 57007. At the time of data collection, Elderkin and Lewis were graduate research assistant and associate professor, respectively, South Dakota University.
\end{abstract}

\begin{abstract}
Vertical biomass distributions for western wheatgrass (Agropyron smithii Rydb.) from 3 locations in western South Dakota were evaluated to determine effects of location, date, topographic position, past grazing history (vigor), and phenological development. A linear, quadratic regression was used for model development and testing, and analysis was by general linear hypothesis testing. All factors except topographic position were significant; however, only phenological development was useful in a general model for estimating utilization from the percentage of height remaining. This factor was best expressed in 3 leaf-classes of 2-4, 5-6, and 7-10 leaves per tiller. Thus, height-weight relationships can be improved as a biomass predictor if separate regressions are used for these 3 phenological classes.
\end{abstract}

Key Words: Agropyron smithii, utilization, vigor, leaf-class, growth form, mixed-grass prairie, South Dakota

Determining forage utilization is a necessary element of managing grazing animals on rangeland. Extended high degrees of use can affect the direction and rate of range trend, so utilization must be monitored if desired results are to be achieved (Heady 1975). Utilization is defined as the proportion of current year's forage production that is consumed or destroyed by grazing animals (Glossary Revision Special Committee 1989). A number of methods are available to estimate herbage utilization (Cook and

Manuscript accepted 20 Aug. 1992.
Stubbendieck 1986), including the use of height-weight ratios. Plant height is easier to measure than biomass, which can approximate annual production at peak standing crop (Mitchell 1983). Because the 2 are strongly correlated, the height-weight method became an early management tool (Lommasson and Jensen 1938, 1943). Although the inherent accuracy of the height-weight method has been questioned (Reid and Pickford 1941), most workers consider it to provide an acceptable estimate of utilization of perennial grasses (Bonham 1989).

Developers and users of height-weight tables have generally assumed that the relationship for a given species does not vary with growth form, location, or plant height (McDougald and Platt 1976). However, early work showed the existence of variation in height-weight ratios among growth forms (Clark 1945, Heady (1950).

Little research has been reported on growth form variations in important range grasses, particularly a rhizomatous species like western wheatgrass (Agropyron smithii Rydb.). Western wheatgrass is a sod-forming, native, perennial with robust spreading rhizomes and mostly vegetative tillers (Johnson and Nichols 1970). Detling and Painter (1983) demonstrated that western wheatgrass has a different growth form when it occurs within highly grazed prairie dog colonies. From a management perspective, significant growth form differences should be identified with more easily recognized conditions, such as condition class, topographic position, or phenological state, in order to be useful in deciding upon specific models. This important topic has not been adequately investigated. 
The objective of this study was to evaluate factors capable of influencing height-weight relationships in western wheatgrass, including date, location, topographic position, long-term grazing pressure, and a structural feature, the number of leaves per tiller. Due to the species' asexual, rhizomatous growth characteristics, the experimental design focused upon individual vegetative tillers. As with other height-weight equations, the actual mean ungrazed height for the sampling population must be known for the model to be applied in the field.

\section{Methods}

\section{Locations}

Height-weight data of western wheatgrass were collected during the summer of 1962 at 3 locations in South Dakota, all representative of the northern mixed prairie (Singh et al. 1983). The Pierre Site $\left(100^{\circ} 35 \mathrm{~W}, 44^{\circ} 22 \mathrm{~N}\right)$ was located about $15 \mathrm{~km}$ west of Pierre. The Cottonwood Site $\left(101^{\circ} 52^{\prime} \mathrm{W}, 43^{\circ} 57^{\prime} \mathrm{N}\right)$ was on the Cotton Field Station, $15 \mathrm{~km}$ west of Phillip. The Antelope Site $\left(103^{\circ} 15^{\prime} \mathrm{W}\right.$, $45^{\circ} 30 \mathrm{~N}$ ) was situated on the Antelope Field Station, approximately $15 \mathrm{~km}$ southwest of Reva.

The climate of the region is semiarid. Typically, the growing season begins during April, and lasts from about 170 days at Cottonwood to 190 days at Pierre. The long-term annual air temperature at Cottonwood is $8^{\circ} \mathrm{C}$, while the growing-season air temperature averages $16^{\circ} \mathrm{C}$ (Sims et al. 1978). The mean annual air temperature at Pierre is approximately $2^{\circ} \mathrm{C}$ warmer than at Cottonwood, while the Antelope location is $3^{\circ} \mathrm{C}$ cooler (unpublished data).

Precipitation at Cottonwood averages $380 \mathrm{~mm} /$ year (Singh et al. 1983). It is slightly higher at Pierre, $430 \mathrm{~mm} /$ year, and lower at Antelope, $320 \mathrm{~mm} /$ year (unpublished data). Precipitation was below normal at all 3 locations during 1961, the year before data collection. It was near normal, $385 \mathrm{~mm}$, at Cottonwood in 1962 and somewhat above normal, $600 \mathrm{~mm}$ and $390 \mathrm{~mm}$, respectively, at Pierre and Antelope.

Soils at all locations are mollisols. At both Cottonwood and Pierre, soils are derived from shales, providing weakly developed clays that are relatively low in organic matter. The soils at Antelope are alluvial, derived from very fine sandy loams. Upland topographic locations are well drained, while areas of soil water accumulation are only moderately well drained.

\section{Field and Laboratory Procedures}

The experiment evaluated the effects of location, date, topographic position, and vigor on the height-weight relationship of western wheatgrass. With the exceptions listed below, stands representing these combinations were identified and located before data were collected. Plants were sampled on the following dates: 10-16 June, 8-13 July, 5-10 August, and 11-15 September 1962.

Vigor was defined on the basis of long-term grazing pressure. In this study, high-vigor plants came from a winter-grazed pasture at Cottonwood and a lightly grazed (utilization $\leq 35 \%$ ) sheep pasture at Antelope, and low-vigor plants came from heavily grazed (utilization $>55 \%$ ) pastures at the 2 locations. Only a high-vigor site was evaluated at Pierre. Because of a grasshopper infestation, the high-vigor pasture at Cottonwood could not be sampled in August and September.

Both upland lowland topographic positions were sampled at Cottonwood and Antelope; only an upland site was evaluated at Pierre.

Stands were selected, following the same logic later described by Daubenmire (1970), within each of the location-vigor-topographic position combinations. Stands were selected to minimize withinlocation variation while concomitantly representing their surrounding conditions. Eight macroplots were then randomly assigned within each stand. Macroplot size was governed by the density of western wheatgrass, and varied from approximately $3 \times 3 \mathrm{~m}$ to $8 \times$ $30 \mathrm{~m}$. Two macroplots were sampled on each of the 4 dates.

Before sampling commenced, the distribution of leaf numbers per tiller was estimated using a paced transect in each macroplot and counting the number of leaves on the nearest healthy plant to each transect point. Transect length varied with macroplot size. Healthy plants were defined as those with ungrazed, live terminal shoots. On the first sampling date, 100 tillers were examined per macroplot. Only 50 tillers were observed on the other dates because of lower than expected variation in the number of leaves per tiller. After analysis, a target population of tillers with 2 to 10 leaves was selected for height-weight observations. This group comprised 95\% of all tillers observed.

After determining the target population of western wheatgrass plants, 2 random transects were established on each macroplot. Ten points were systematically located along each transect, with the distance between points varying with transect length. The closest suitable tillers having each respective leaf number in the target population (2-10) were collected at each point for subsequent measurements. The specimens were cut at ground level and carefully inserted in labeled collection tubes.

The field data represented only a single growing season. This was common occurrence in experimental designs prior to the 1970's. Two years of data do provide a minimal statistical measure of how repeatable means are over time; however, from a biological perspective an extra year of data for this study may not be more informative than estimates from 1 year. Requirements for longterm data appear to be positively correlated with how xeric abiotic conditions are (Miles 1979). Sharp et al. (1992) graphically demonstrated such a principle in the salt desert shrub zone of southern Idaho. Productivity of western wheatgrass in the northern plains is more uniform, except during periods of extended drought, because the species begins growth earlier than competing warm-season species and has the ability to extract soil water from throughout the solum (Majerus 1975). The average to above-average precipitation in the year of sampling, along with the degree of site variability in the original experimental design, allowed us to postulate that observed western wheatgrass tiller growth forms, as expressed in location and other stratified site variables, provided sufficient variation to allow management interpretation.

In the laboratory, the total length of each tiller was measured from its base to the tip of the highest leaf and then segregated into 1 of 8 equal $8-\mathrm{cm}$ height-classes, ranging from 0 to $7.9 \mathrm{~cm}$ (heightclass 1) to 56.0 to $63.9 \mathrm{~cm}$ (height-class 8 ). Within each height-class tillers were combined into groups, keeping the number of leaves per tiller constant within group. A maximum of 5 tillers was allowed per group, but the number of groups in a height-class was not limited.

Next, the tillers were individually cut into 10 equal segments. The combined segments for each group were oven-dried at $104^{\circ} \mathrm{C}$ for 24 hours and weighed to the nearest $0.0001 \mathrm{~g}$. A total of 1,243 groups were weighed (Table 1), and they became the experimental unit for data analysis.

\section{Data Analysis}

Initially, the segment weight data were combined so resulting predictive models would be on the basis of cumulative weight removed for the proportion of total height remaining. These cumulative weight removed/height remaining data were determined for each $10 \%$ of plant height within height-class, grazing treatment (vigor), topographic position, location, and date. The mean number of leaves per tiller was also a part of each group's data record. Next, the cumulative weight data were divided by the total weight of their respective groups to normalize the data to a range of 0 to 1 .

Both multiple linear and nonlinear regressions were conducted 
Table 1. Individual regression models of relative weight removed $(Y)$ and relative height remaining $(X)$, as modified by site, date, grazing history (vigor), and topographic position. Small letters designate significant differences $(P<.01)$ between models, within groupings. Sample size (groups of western wheatgrass tillers) is denoted by $n$.

\begin{tabular}{|c|c|c|c|c|c|}
\hline Treatment Effect & Model & & $R^{2}$ & Sy.x & $\mathrm{n}$ \\
\hline $\begin{array}{l}\text { A. Site } \\
\text { Pierre } \\
\text { Cottonwood } \\
\text { Antelope }\end{array}$ & $\begin{array}{l}\mathcal{Y}=1.027-.0150 \mathrm{X}+4.36 \mathrm{E}-05 \mathrm{X}^{2} \\
\mathrm{Y}=1.039-.0172 \mathrm{X}+6.48 \mathrm{E}-05 \mathrm{X}^{2} \\
\mathrm{Y}=1.028-.0158 \mathrm{X}+5.02 \mathrm{E}-05 \mathrm{X}^{2}\end{array}$ & $\begin{array}{l}\mathbf{a} \\
\mathbf{b} \\
\mathbf{c}\end{array}$ & $\begin{array}{l}.978 \\
.984 \\
.978\end{array}$ & $\begin{array}{l}.051 \\
.044 \\
.051\end{array}$ & $\begin{array}{l}155 \\
422 \\
666\end{array}$ \\
\hline $\begin{array}{l}\text { B. Date } \\
\text { 10-16 June } \\
\text { 8-13 July } \\
\text { 5-10 August } \\
\text { 11-15 Sept }\end{array}$ & $\begin{array}{l}\hat{Y}=1.027-.0187 X+8.29 E-05 X^{2} \\
\hat{Y}=1.032-.0161 X+5.39 E-05 X^{2} \\
\hat{Y}=1.035-.0139 X+3.10 E-05 X^{2} \\
\hat{Y}=1.036-.0138 X+2.94 E-05 X^{2}\end{array}$ & $\begin{array}{l}\mathrm{a} \\
\mathrm{b} \\
\mathrm{c} \\
\mathrm{c}\end{array}$ & $\begin{array}{l}.993 \\
.990 \\
.986 \\
.983\end{array}$ & $\begin{array}{l}.029 \\
.034 \\
.041 \\
.045\end{array}$ & $\begin{array}{l}396 \\
382 \\
272 \\
193\end{array}$ \\
\hline $\begin{array}{l}\text { C. Grazing History (Vigor) } \\
\text { Light Grazing (High) } \\
\text { Heavy Grazing (Low) }\end{array}$ & $\begin{array}{l}\hat{Y}=1.030-.0155 X+4.85 E-05 X^{2} \\
\hat{Y}=1.033-.0168 X+6.13 E-05 X^{2}\end{array}$ & $\begin{array}{l}\mathbf{a} \\
\mathbf{b}\end{array}$ & $\begin{array}{l}.979 \\
.981\end{array}$ & $\begin{array}{l}.050 \\
.047\end{array}$ & $\begin{array}{l}674 \\
569\end{array}$ \\
\hline $\begin{array}{l}\text { D. Topographic Position } \\
\text { Upland } \\
\text { Bottom }\end{array}$ & $\begin{array}{l}\hat{Y}=1.034-.0162 X+5.47 E-05 X^{2} \\
\hat{Y}=1.029-.0160 X+5.39 E-05 X^{2}\end{array}$ & $\begin{array}{l}\mathbf{a} \\
\mathbf{a}\end{array}$ & $\begin{array}{l}.980 \\
.979\end{array}$ & $\begin{array}{l}.049 \\
.050\end{array}$ & $\begin{array}{l}667 \\
576\end{array}$ \\
\hline $\begin{array}{l}\text { E. Leaf-Class } \\
\text { 2-4 Leaves } \\
\text { 5-6 Leaves } \\
\text { 7-10 Leaves }\end{array}$ & $\begin{array}{l}\hat{Y}=1.031-.0184 X+7.86 \mathrm{E}-05 \mathrm{X}^{2} \\
\hat{Y}=1.034-.0168 \mathrm{X}+6.10 \mathrm{E}-05 \mathrm{X}^{2} \\
\hat{Y}=1.029-.0141 \mathrm{X}+3.37 \mathrm{E} 05 \mathrm{X}^{2}\end{array}$ & $\begin{array}{l}\mathbf{a} \\
\mathbf{b} \\
\mathbf{c}\end{array}$ & $\begin{array}{l}.992 \\
.982 \\
.985\end{array}$ & $\begin{array}{l}.031 \\
.047 \\
.043\end{array}$ & $\begin{array}{l}272 \\
491 \\
480\end{array}$ \\
\hline F. All Variables & $\hat{\mathrm{Y}}=1.032-.0161 \mathrm{X}+5.43 \mathrm{E}-05 \mathrm{X}^{2}$ & & .979 & .050 & 1,243 \\
\hline
\end{tabular}

to determine the best-fitting model for predicting the proportion of cumulative weight removed (Y) from the proportion of height remaining $(\mathrm{X})$ across all variables. A quadratic model was most suitable because of its low residual error:

$$
\gamma=\beta_{0}+\beta_{1} X+\beta_{2} X^{2}+\epsilon
$$

The various treatment effects (date, location, topographic location, and vigor) were compared by testing the general linear hypothesis,

$$
H_{0}: \beta_{11}-\beta_{12}=0 ; \beta_{21}-\beta_{22}=0
$$

where the second subscript refers to the jth model for each variable, separately, using the entire data set. All possible combinations were tested for location, which had a treatment size larger than 2; however, only contiguous dates were evaluated, based upon the premise that grass structure geometry changes evenly. The hypothesis test compares the ratio of the mean square due to the hypothesis to the summed mean squares of the individual models with an $F$ distribution (Draper and Smith 1966):

$$
F=\frac{(\mathrm{SSW}-\mathrm{SSR}) / \mathrm{q}}{\mathrm{SSR} /(\mathrm{n}-\mathrm{p})}
$$

where SSW = residual SS from the pooled regression, $S S R=$ summed residual $S S$ from the individual models, $n=$ total sample size (all models), $p=$ number of variables (all models), and $q=p-$ number of variables (pooled model).

The number of leaves per tiller ranged from 2 to 10 . After preliminary analysis to empirically maximize between-group variation, this variable was combined into 3 groups $(2-4,5-6,7-10$ leaves), hereafter called leaf-class, and tested for significance as described above. In addition, the correlation between date and leaf-class was examined for redundancy as measures of plant growth.

Following hypothesis testing, a general utilization model was developed for western wheatgrass in the northern mixed prairie that included the variables deemed significant in the statistical analysis.

\section{Results}

Individual regression models for the different locations, sampling periods, grazing histories, topographic positions, and phenological stages (leaf class) are shown in Table 1. Location changed the model for each of the 3 possible combinations $(P<0.001)$. Location effects integrate a myriad of abiotic factors, precluding them from being incorporated into a generalized height-weight model, so this source of variation was combined to make it representative of overall conditions in the northern mixed prairie.

Seasonal development affected height-weight relationships in western wheatgrass for the first 3 sampling periods $(P<0.001)$. There was no apparent difference between the third and fourth sampling periods $(P=0.248)$, reflecting the structural stability of western wheatgrass after senescence.

The effect of long-term heavy grazing (low vigor) caused the vertical weight distribution of western wheatgrass to be slightly less concentrated near the base of the tiller in comparison to long-term light grazing (high vigor) $(P<0.001)$. Topographic position did not exert an influence on the height-weight relationship of western wheatgrass $(P=0.136)$. Regression models for the 3 leaf-classes were all different $(P<0.001)$.

Expectedly, a strong positive correlation existed between date of sampling and leaf-class. Although both variables were significant when included in the same model, the standard errors of the estimate were essentially the same for the model containing only leaf-class and that containing date and leaf-class. We therefore decided that leaf-class should represent plant growth as an independent variable in model development, and date was dropped.

When height-weight models based upon leaf-class were stratified by past grazing pressure, the 6 equations were different $(P<0.001)$. Nonetheless, the practical application of these differences was marginal. Within all 3 leaf-classes, predicted differences in utilization for heavily and lightly grazed plants were always less than $2 \%$.

Thus, a single generalized model for western wheatgrass is presented, based upon leaf-class as a phenological state (Fig. 1). Since the heavy and light grazing treatments represented extremes not usually recommended for proper management of mixed-grass 


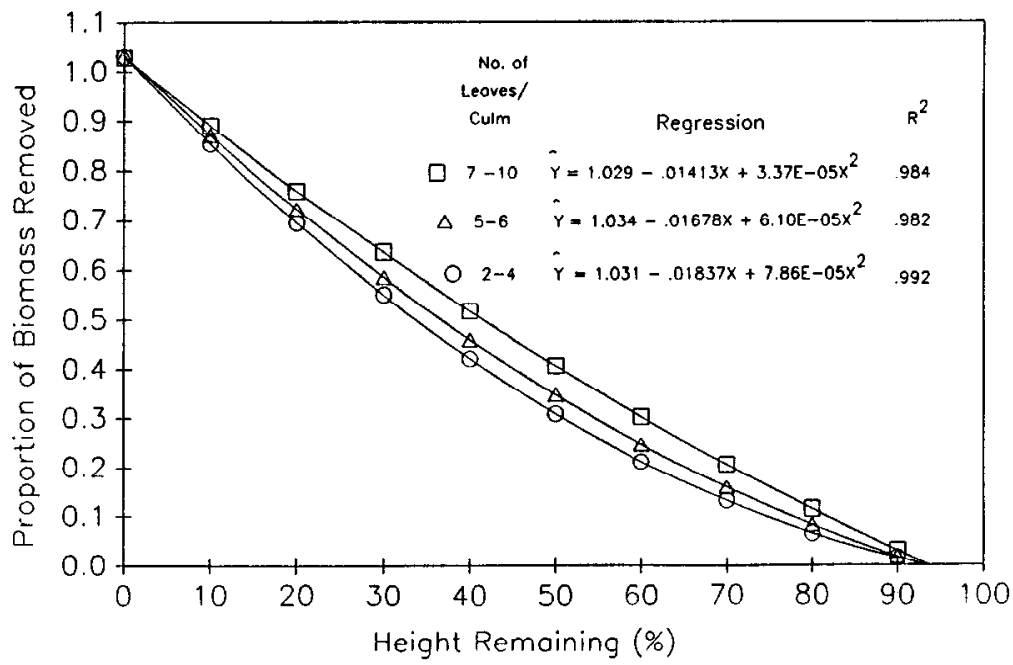

Fig. 1. Regression models for cumulative weight removed (\%) of western wheatgrass based upon height remaining (\%) and leaf-class, where leaf-class refers to the mean number of leaves per tiller.

prairie in the northern plains (Lewis et al. 1956), combining them was expected to portray a more moderate grazing history.

\section{Discussion and Conclusions}

The significant factors we found to affect western wheatgrass height-weight relationships were location, history of grazing intensity, and seasonal plant development. Of these, location was only useful as an expression of spatial variation within the northern mixed prairie because it integrates a myriad of biotic and abiotic factors. The results demonstrate that utilization estimates for a particular location can always be slightly improved by calculating model coefficients using site-specific data.

Past grazing history differences, although significant in our study, may not be important from a management perspective. The differences in utilization between the lightly grazed and heavily grazed pastures were smaller than those for differences in plant development. If exactly $60 \%$ utilization was desired at a growth stage of 4 to 6 leaves, for example, the estimated height remaining for a heavy-use pasture, $28.5 \%$, is essentially identical to that estimated by the general model, $28.9 \%$.

Pastures that are lightly grazed on a long-term basis do not normally require accurate observations of utilization because critical limits are never approached. However, height-weight relationships under light use can become important when managing land for wildlife habitat, such as for sharp-tailed grouse (Johnsgard 1973).

The effect of phenological development on growth form was most interesting, particularly the manner in which the number of leaves per tiller categorized into leaf class. According to our analysis, little change occurred before 5 leaves appeared, and the same static situation was evident after the seventh leaf emerged.

A regression of leaf number with date indicated that this critical leaf-class of 5-6 leaves was most dominant in mid-July. Cid (1985) also demonstrated that apparent maximum western wheatgrass productivity occurs during this same period, when there are about 6 leaves per tiller. The rate of increase preceding maximum productivity, as well as the rate of decrease following it, are quite rapid (Redmann 1978), indicating a potential for greatest changes in plant geomctry. Unfortunately, correlations between grass structure and seasonal net productivity have not been directly studied.

Two approaches to accounting for plant development, as measured by leaf-class, were examined: Use of dummy variables in 1 multiple regression, and use of 3 separate regressions. A single regression with dummy variables provides a simpler quantitative tool that can still account for variation due to a qualitative vari- able, such as leaf-class (Draper and Smith 1966). However, the number of dummy variables required in a quadratic regression adds undesirable complexity to a tool designed for use in field offices. Therefore, separate regressions were used for the final model.

Height-weight models give managers the ability to efficiently assess utilization throughout a grazing period. The method is nondestructive, can be accomplished in the field, and requires only sufficient cages to furnish an estimate of mean ungrazed plant height. The principal utility of the models presented in this report results from their depiction of how seasonal development of western wheatgrass causes significant changes in the height-weight relationship.

\section{Literature Cited}

Bonham, C.D. 1989. Measurements for terrestrial vegetation. John Wiley and Sons, N.Y.

Cid, M.S. 1985. Effects of grazing exposure history and defoliation on silicon concentration of Agropyron smithii. M.S. Thesis, Colorado State University, Fort Collins,

Clark, I. 1945. Variability in growth characteristics of forage plants on summer range in central Utah. U. Forest. 43:273-283.

Cook, C.W., and J. Stubbendieck (ed.) 1986. Range research: basic problems and techniques. Rev. ed. Soc. Range Manage., Denver.

Daubenmire, R. 1970. Steppe vegetation of Washington. Washington Agr. Exp. Sta. Tech. Bull. 62. Washington State Univ., Pullman.

Detling, J.K., and E.L. Painter. 1983. Defoliation responses of western wheatgrass populations with diverse histories of prairie dog grazing. Oecologia 57:65-71.

Draper, N.R., and H. Smith. 1966. Applied regression analysis. John Wiley \& Sons, Inc., N.Y.

Glossary Revision Special Committee. 1989. A glossary of terms used in range management. Soc. Range Manage., Denver.

Heady, H.F. 1950. Studies on bluebunch wheatgrass in Montana and height-weight relationships of certain range grasses. Ecol. Mono. 20:55-81.

Heady, H.F. 1975. Rangeland management. McGraw-Hill Book Co., N.Y. Johnsgard, H.W. 1973. Grouse and quails of North America. Univ. Nebraska Press, Lincoln.

Johnson, J.R., and J.T. Nichols. 1970. Plants of South Dakota grasslands. Bull. 566. South Dakota Agr. Exp. Sta., Brookings.

Lewis, J.K., G.M. Van Dyne, L.R. Albee, and F.W. Whetzal. 1956. Intensity of grazing: its effect on livestock and forage production. Bull. 459. South Dakota Agr. Exp. Sta., Brookings.

Lommasson, T., and C. Jensen. 1938. Grass volume tables for determining range utilization. Science 87:444.

Lommasson, T., and C. Jensen. 1943. Determining utilization of range grasses by height-weight tables. J. Forest. 41:589-593. 
Majerus, M.E. 1975. Response of root and shoot growth of three grass species to decreases in soil water potential. J. Range Manage. 28:473-476.

McDougald, N.K., and R.C. Platt. 1976. A method of determining utilization for wet mountain meadows on the Summit Allotment, Sequoia National Forest, California. J. Range Manage. 29:497-501.

Miles, J. 1979. Vegetation dynamics. Chapman and Hall, London.

Mitchell, J.E. 1983. Analysis of forage production for assessments and appraisals. USDA Forest Serv. Gen. Tech. Rep. RM-98. Rocky Mountain Forest and Range Exp. Sta., Fort Collins, Colo.

Redmann, R.E. 1978. Seasonal dynamics of carbon dioxide exchange in a mixed grassland ecosystem. Can. J. Bot. 56:1995-2005.

Reid, E.H., and G.D. Pickford. 1941. A comparison of the ocular-estimateby-plot and the stubble-height methods of determining percentage utilization of range grasses. J. Forest. 39:935-941.
Sharp, I.A., K. Sanders, and N. Rimbey. 1992. Variability of crested wheatgrass production over 35 years. Rangelands 14:153-168.

Sims, P.L., J.S. Singh, and W.K. Lauenroth. 1978. The structure and function of ten western North American grasslands: I. Abiotic and vegetational characteristics. J. Ecol. 66:251-285.

Singh, J.S., W.K. Lauenroth, R.K. Heitschmidt, and J.L. Dodd. 1983 Structural and functional attributes of the vegetation of northern mixed prairie of North America. The Bot. Rev. 49:117-149.

USDA Forest Service. 1937. Range plant handbook. U.S. Gov. Print. Off., Washington, D.C. 